\title{
Wheat genetic resources for breeding on adaptability
}

\author{
M.A. Yessimbekova*, M.Sh. Suleimenova, K.B. Mukin \\ Kazakh Research Institute of Agriculture and Plant Growing, Astana, Kazakhstan
}

DOI 10.18699/ICG-PlantGen2019-04

(c) Autors, 2019

* e-mail: minura.esimbekova@mail.ru

\begin{abstract}
High temperature can be one of the main factors limiting the productivity of all agricultural crops, including wheat. In this regard, understanding the physiological problems associated with stress caused by high temperature is of great importance. The aim of the studies was to phenotype wheat germplasm (Triticum aestivum L.) to assess the potential of using the NDVI (normalized difference vegetation index) and CTD (canopy temperature depression) measurements to identify wheat genotypes that show a high correlation of productivity with heat tolerance (CTD) and drought resistance (NDVI) cultures in the foothill and dry-steppe zones of the Trans-lli Alatau. A trend of increasing productivity with increasing CTD $(r=0.67)$ was revealed. Five winter wheat accessions were selected as sources of productivity and adaptability to high temperatures. Monitoring of the wheat gene pool using GreenSeeker, an optical sensor, showed a change in the plant biomass index (NDVI) value depending on the conditions of cultivation and the phase of development. An association ( $r=0.64)$ between NDVI and the yield of winter wheat was established. For spring wheat, a high degree of NDVI correlation $(r=0.51-0.54)$ with spike length, number of spikelets, kernels and weight of kernels per spike was noted.

Key words: winter and spring bread wheat; T. aestivum L.; yield productivity; biomass index.
\end{abstract}

\section{Introduction}

Worldwide, global climate change is objectively observed and projected. The Second National Communication on the UN Framework Convention on Climate Change of Kazakhstan indicates that the average temperature in the region has risen by more than $0.15^{\circ} \mathrm{C} / 10$ years (Eserkepova et al., 2009). High temperature can be one of the main factors limiting the productivity of all agricultural crops, including wheat. Understanding the physiological problems associated with stress caused by high temperature is of great importance. Various physiological mechanisms contribute to the heat tolerance of plants. The canopy temperature is a function of many environmental factors: soil water status, air temperature, relative humidity, and radiation (Amani et al., 1996). Canopy temperature depression (CTD) is a good indicator of the genotypes' relevance to a given environment. Experimental data showed a clear association of CTD with yield (Reynolds et al., 1998, 2001, 2007; Saint Pierre et al., 2010; Cossani, Reynolds, 2012; Pinto, Reynolds, 2015). Drought is a major factor limiting the yield of wheat throughout the world. The degree of modification depends on the variety, growth stage, duration and intensity of stress (Araus et al., 2002; Barnabas et al., 2008). The best option for increasing yields and crop stability is the development of drought-resistant crop varieties (Fischer, Maurer, 1978; Rajaram, 1996). It has recently become possible to perform indirect assessments of agronomic and physiological features using spectral reflection methods associated with photosynthetic activity and plant productivity (Verhulst, Govaerts, 2010). Among the most widely used simple methods is the normalized differential vegetation index (NDVI). NDVI is a non-destructive method for effective assessment of total dry matter (TDM), leaf area index (LAI) in wheat and barley. NDVI positively correlates with grain yield and can serve as an indirect criterion for the selection of productive forms. These indicators are very useful for assessing the photosynthetic ability of plants and yield (Sharma et al., 2011).

\section{Materials and methods}

Field experiments were conducted during the growing season of 2014/2016 on the experimental field plots of the gene pool department of Kazakh Research Institute of Agriculture and Plant Growing in 2 soil-climatic zones of the Trans-Ili Alatau $\left(48^{\circ} \mathrm{N}, 77^{\circ} \mathrm{E}\right): 1$ ) rain fed conditions of the foothill zone; 2) semi-arid conditions of the dry-steppe zone.

In the crop rotation system, wheat was placed annually after a three-year alfalfa. Fertilizers, applied according to the technology adopted in the zone, herbicides, fungicides and insecticides were used as needed to minimize the impact of weeds, diseases and insects. Material: The objects of the study were winter, facultative and spring bread wheat accessions from 3 International nurseries of CIMMYT 1) Winter Wheat Eastern European Regional Yield Trial (WWEERYT); 2) Facultative and Winter Wheat Observation Nursery (FAWWON); 3) Kazakhstan-Siberian Network on Wheat Improvement (KASIB). Methods: CTD was measured as the difference between air temperature and canopy temperature (Reynolds et al., 1998). NDVI measurements were conducted using GreenSeeker, a portable optical sensor unit (Trimble Navigation Limited, Sunnyvale, CA, USA). The stress susceptibility index (SSI) was calculated as follows: $\mathrm{SSI}=(\mathrm{Yp}-\mathrm{Ys}) / \mathrm{Yp} * 100$, where $\mathrm{Ys}$ is the yield of the genotype under stressful conditions; Yp is the yield of the genotype in non-stressful conditions. The data were analyzed using STATISTICA 10 (StatSoft).

\section{Results and discussion}

The international exchange of varieties and breeding materials is of great practical value for the creation of new varieties. 
For more than 20 years, Kazakhstan has been participating in the assessment of winter wheat nurseries formed by the International Program of CIMMYT. The meteorological conditions of the 2014/2016 research years were favorable both in thermal, water and energy terms. According to the CTD measurements, the detected genotypes of WWEERYT nurseries were divided into 3 groups: the warmest varieties were included in 1 and 2 groups $\left(\mathrm{CTD}=11.4-12.8^{\circ} \mathrm{C}\right)$ with the productivity scale from 225.0 to $610.0 \mathrm{~g} / \mathrm{m}^{2}$. The most numerous were the $3 \mathrm{rd}$ group $\left(69 \mathrm{pcs}, \mathrm{CTD}=13.0-14.20^{\circ} \mathrm{C}\right)$ with the yield from 460.0 to $910.0 \mathrm{~g} / \mathrm{m}^{2} .17$ high-yielding accessions $\left(\geq 650 \mathrm{~g} / \mathrm{m}^{2}\right)$ have been identified as promising. The coolest accession was KS89180B from the USA (CTD $=$ $=14.2{ }^{\circ} \mathrm{C}$, yielding $710.0 \mathrm{~g} / \mathrm{m}^{2}$ ).

The most productive in the group of cool accessions was a variety from Ukraine, 'Kharkovskaya-106' $\left(\mathrm{CTD}=13.6{ }^{\circ} \mathrm{C}\right.$, yielding $910.0 \mathrm{~g} / \mathrm{m}^{2}$ ). A trend to increase productivity with increasing CTD was revealed. A positive correlation is noted between CTD and average yield in 128 winter wheat varieties and lines $(r=0.67)$. Five accessions of the WWEERYT nursery with a high correlation between CTD and productivity were identified as sources of productivity and adaptability to high temperatures (heat tolerance). The yield of any plant organism, including winter wheat, is considered as the end product of the photosynthetic ability, which begins with the process of photosynthesis. The leaf area index (LAI) for Kazakhstan breeding productive varieties ranged from 48.2 to 71.2 thousand $\mathrm{m}^{2} /$ ha (the absorption energy $1.94-2.41 \%$ PAR). The total dry matter (TDM) ranged from 13.55 to $16.85 \mathrm{t} / \mathrm{ha}(\mathrm{St}=12.74 \mathrm{t} / \mathrm{ha})$, which ensured the grain yield from 5.12 to $7.41 \mathrm{t} / \mathrm{ha}$. The largest LAI ( 71.2 thousand $\mathrm{m}^{2} / \mathrm{ha}$ ) was with the variety 'Kazakhstanskaya-16', able to absorb and assimilate solar energy with a high efficiency (2.41\% PAR), which provided the formation of $16.85 \mathrm{t} / \mathrm{ha}$ of TDM and of $7.41 \mathrm{t} /$ ha of grain yield.

Normalized Differential Vegetation Index (NDVI) measures the amount of green vegetation in the area. In this regard NDVI was used as an indirect criterion for the selection of productive forms. The NDVI values for winter wheat accessions in rainfed conditions of the Trans-Ili Alatau foothill zone varied from 0.40 to 0.81 . The relationships between NDVI, physiological features and productivity of Kazakhstan winter wheat varieties are classified as average $(r=0.37-0.41)$. However, a high degree of correlation $(r=0.71)$ observed between NDVI and heading time (HT, the number of days from January 1) allowed us to reveal, within 6 HT groups of winter wheat accessions, a high degree of correlation $(r=0.64)$ between NDVI and productivity. NDVI measurements in the foothill zone on the spring bread wheat accessions from the KASIB international nursery showed the ability of the NDVI to differentiate wheat genotypes. High values of NDVI (0.70-0.75) were observed at the heading stage, which, as was established, can serve as an indicator of the good plant state before transition to the reproductive stage.

For spring wheat early maturing genotypes, there was a marked decrease in NDVI during transition from the heading stage to the grain filling period, Figure 1. It is hypothesized
(Sharma et al., 2011) that early maturing genotypes with high values of NDVI (0.70-0.75) are important for early sowing, for they will better tolerate early drought, which occurs in the prewinter and early spring months in many parts of Central Asia. Twenty-eight medium maturity genotypes with stable NDVI values (0.70) keep green leaves for long and better tolerate terminal heat stress, which often occurs in the foothill zone of the Trans-Ili Alatau in the third decade of June and July. A high degree of correlation between NDVI and spike length (SL), number of spikelets (NSS), number of kernels (NKS), and weight of kernels (WKS) per spike $(r=0.54 ; 0.51 ; 0.55$; 0.51 , respectively) were noted.

Gene expression is not the same in different environmental conditions. The water and heat stress of the dry-steppe zone caused a decrease in the photosynthetic ability and, as a result, a decreased NDVI (0.20-0.79) (Figure 2).

The stress susceptibility index (SSI) determined by a comparative analysis of the spring wheat productivity traits in the conditions of the foothill and dry-steppe zones allowed indicating five accessions - 'Lutescens 259', 'Erythrospermum 55/94', 'Stepnaya 17', 'Samgau', and 'Alpha-79' - with the lowest SSI for all analyzed traits. There are correlations of varying degrees between NDVI and PH (plant height), NSS, SL, WKS, NKS $(r=0.58 ; 0.50 ; 0.37 ; 0.30$; and 0.20 , respectively).

\section{Conclusions}

CTD is an integrated result of the environmental conditions affecting the absorption energy and the evaporation mechanism (Amani et al., 1996). The research results showed the possibility of using the CTD method as an indirect selection criterion for heat tolerance in the southeastern part of Kazakhstan: a high genetic correlation $(r=0.67)$ between CTD and productivity was established. Five accessions from the WWEERYT nursery, distinguished by a high correlation coefficient between the CTD index and productivity, have been transferred for use in breeding for productivity and heat tolerance. As a result of the research, the ability of NDVI to differentiate wheat varieties at different stages of growth and the ability to use NDVI values as predictors of wheat yield were established. In the foothill zone of the Trans-Ili Alatau, within six marked ripeness groups, a connection $(r=0.64)$ between the grain yield of winter wheat and the NDVI was established.

For spring wheat, a marked high degree correlation of NDVI with SL, NSS, NKS and WKS $(r=0.54 ; 0.51 ; 0.55$; 0.51 , respectively) was revealed. The results obtained in these experiments show that drought stress significantly reduced the NDVI. NDVI values varied from 0.20 to 0.79 . The correlations of varying degrees between NDVI and PH, NSS, SL, WKS, and NKS $(0.58 ; 0.50 ; 0.37 ; 0.30$; and 0.20 , respectively) are noted. The results show that the germplasm included in the study represents significant genotypic variations, which can be useful for programs to improve winter and spring wheat productivity and resistance to heat and drought. NDVI broadens the understanding of various management methods within an agro-ecological environment and shows how management affects and determines the efficiency of the resource use. 


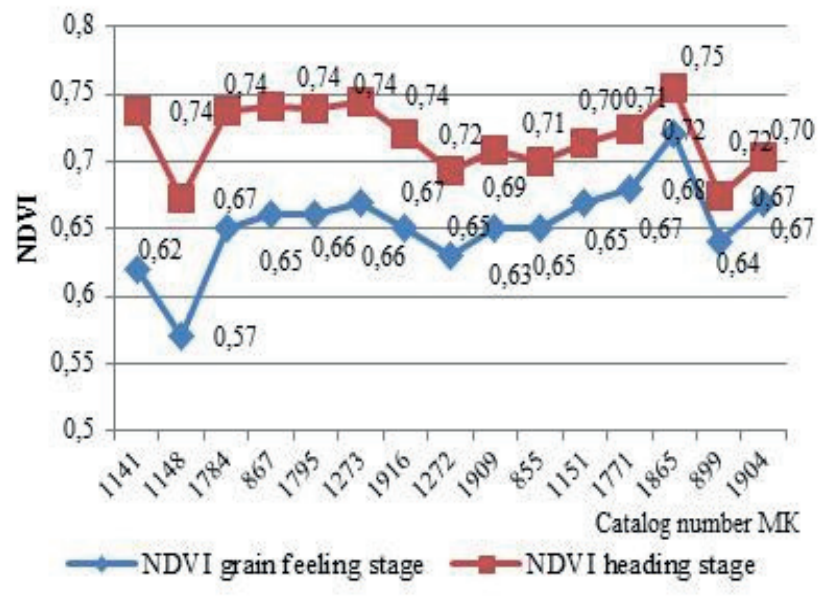

Figure 1. NDVI of spring bread wheat accessions from KASIB nursery under rainfed conditions at 2 growth stages (heading and grain filling stage), 2016.

\section{References}

Amani I., Fisher R.A., Reynolds M.P. Canopy Temperature Depression Association with Yield of Irrigated Spring Wheat Cultivars in a Hot Climate. J. Agron. Crop Sci. 1996;176(2):119-129. DOI 10.1111/j.1439-037X.1996.tb00454.x.

Araus J.L., Slafer G.A., Reynolds M., Royo C. Plant breeding and drought in C3 cereals: What should we breed for? Ann. Bot. 2002; 89:925-940. DOI 10.1093/aob/mcf049.

Barnabas B., Jager K., Feher A. The effect of drought and heat stress on reproductive processes in cereals. Plant Cell Environ. 2008;31(1): 11-38. DOI 10.1111/j.1365-3040.2007.01727.x.

Cossani C.M., Reynolds M.P. Physiological Traits for Improving Heat Tolerance in Wheat. Plant Physiol. 2012;160(4):1710-1718. DOI: 10.1104/pp.112.207753.

Eserkepova I., Kryukova V., Dolgikh S., Idrisova V., Cherednichenko A., Sergazina G. The Second National Communication of the Republic of Kazakhstan on the UN Framework Convention on Climate Change. 2009. Available at: https://unfccc.int/resource/docs/natc/ kaznc2r.pdf.

Fischer R.A., Maurer R. Drought resistance in spring wheat cultivars. I. Grain yield response. Aust. J. Agric. Res. 1978;29(5):897-907. DOI 10.1071/AR9780897.

Pinto R.S., Reynolds M.P. Common genetic basis for canopy temperature depression under heat and drought stress associated with optimized root distribution in bread wheat. Theoretical Applied Gen. 2015;128(4):575-585. DOI 10.1007/s00122-015-2453-9.

Rajaram S., Braun H.J., Ginkel M.V. CIMMYT's approach to breed for drought tolerance. Euphytica. 1996;92:147-153. DOI 10.1007/ BF00022840.

Reynolds M.P., Ortiz-Monastereo J.I., McNab A. Application of physiology in wheat breading. Mexico, D.F.: CIMMYT, 2001;1-240.

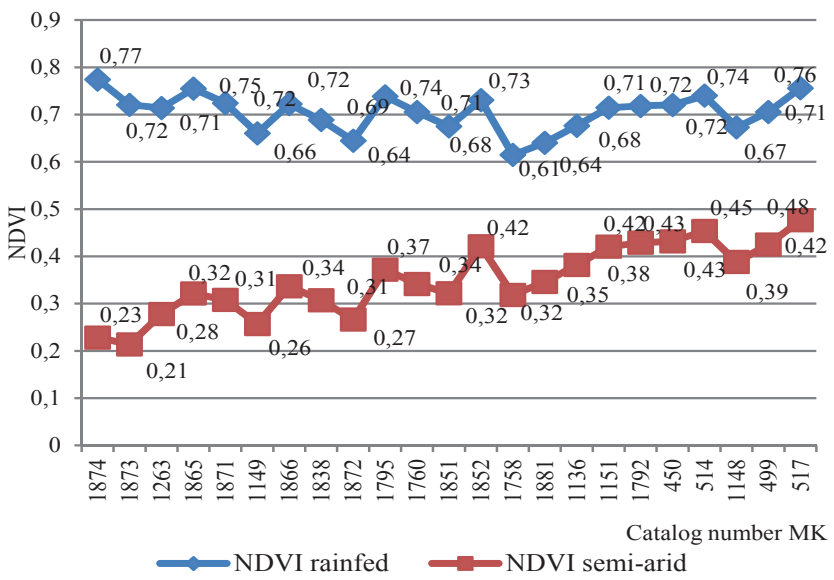

Figure 2. The values of the NDVI measurements of the KASIB spring wheat nursery in the conditions of the foothill and dry-steppe zones of the Trans-Ili Alatau, 2016.

Reynolds M.P., Saint Pierre C., Abu S.I. Saad, Vargas M., Condon A.G. Evaluating potential genetic gains in wheat associated with stressadaptive trait expression in elite genetic resources under drought and heat stress. Crop Sci. 2007;47:172-189. DOI:10.2135/cropsci 2007.10.0022IPBS.

Reynolds M.P., Singh R.P., Ibrahim A., Ageeb O.A.A., Larque-Saavedra A., Quick J.S. Evaluating physiological traits to complement empirical selection for wheat in warm environments. Euphytica. 1998; 100:85-94. DOI:10.1023/A:1018355906553.

Saint Pierre C., Crossa J., Manes Y., Reynolds M.P. Gene action of canopy temperature in bread wheat under diverse environments. Theoretical Applied Gen. 2010;120(6):1107-1117. DOI 10.1007/ s00122-009-1238-4.

Sharma R.C., Islomov S., Yulshadev T., Khalikulov Z., Ziyadullaev Z. Diversity among winter wheat germplasm for NDVI (normalized difference vegetation index) under terminal heat stress in Central Asia. Proc. Int. Conf. "Diversity, Characterization and Utilization of Plant Genetic Resources for Enhanced Resilience to Climate Change". Baku, 3-4 October 2011. Baku, 2011;21-26.

Verhulst N., Govaerts B. The normalized difference vegetation index (NDVI) GreenSeekerTM handheld sensor: Toward the integrated evaluation of crop management. Part A: Concepts and case studies. Mexico, D.F.; CIMMYT, 2010;1-12.

Verhulst N., Govaerts B. The normalized difference vegetation index (NDVI) Green SeekerTM handheld sensor: Toward the integrated evaluation of crop management. Part B: User guide. Mexico, D.F.; CIMMYT, 2010;1-8.

Conflict of interest. The authors declare no conflict of interest. 